\title{
On the Early History of the Brahmanical Yugas
}

\author{
Vincent Eltschinger
}

Albert Hoffstädt's best friend, Virgil (Publius Vergilius Maro, 7O-19 BCE), repeatedly dealt with the Hesiodic myth of the metallic races and its conception of a Golden Age (aurea aetas), making himself responsible both for its "integration into the Roman history and imaginaire"1 and for influential innovations in its narrative structure and meaning. Like his near contemporaries Catullus, Horace, and Ovid, Virgil made frequent use of this myth to express his feelings and inclinations in the much troubled political circumstances of the end of the Republic and the early years of the Empire. Catullus and Horace had resorted to the motif of the Iron Age to describe the climate of moral depravation and political violence that, due to the neglect of pietas, threatened civil institutions and freedom. From his very first remarks on the Golden Age in the fourth Eclogue, and probably still in support of Antony, Virgil repeatedly expressed his belief in a possible restoration of the Golden Age. In the Aeneid, the advent of Augustus coincided with the return of the aurea aetas, which rural Italy had been embodying since the very foundation of the Urbs. Virgil's Georgics and Aeneid thus came close to the new regime's propagandistic uses of the myth, whereas Ovid argued that the Augustan restoration of peace and laws was not to be confounded with the spontaneity of justice that characterized the Golden Age. A few decades later, Seneca and others welcomed Nero as the founder of a saeculum felix, which, again, coincided with the regime's ideology and self-legitimation strategies, often resorting to prophecies.

In Virgil as well as in his influential model, Aratus's Phenomena, the four main features of the aurea aetas are the absence of war, the absence of travels (made unnecesary by autarchy), nature's spontaneous abundance, and the humans' natural practice of piety and justice (other motifs include vegetarianism and the commensality of gods and humans). While yielding a similar picture of the Golden Age, Ovid's Metamorphoses (1.90-150) provide a more systematic account of the gradual degeneration of human society. In the Silver Age (or race, argentea proles) the four seasons make their appearance with hot summers and cold winters forcing humans to seek shelter, whereas the Bronze Age

1 Jacqueline Fabre-Serris, Mythologie et littérature à Rome: La réécriture des mythes aux Iers siècles avant et après J.-C. (Lausanne: Éditions Payot, 1998), 29. 
(aenea proles) sees an increase in cruelty. The fourth and last period, the Iron Age (aetas ferrea), characterizes itself by the disappearance of all virtues (honor, truthfulness, faith) and their replacement by vices such as treachery, violence and greed; crime, theft, and mistrust are substituted for justice; war and seafaring appear together with land allotment, agriculture, and mining.

Directly or indirectly, all known versions of the myth go back to Hesiod's (seventh century вСЕ) original account in the Works and Days (106-202). Here, the history of mankind is divided into five successive states referred to as "races," with heroes or demi-gods (many of them died at Troy, the survivors living in secluded islands under king Kronos) appearing between the Bronze and Iron Races. In the time of Kronos, the Golden Race, dear to the gods, lived a god-like life without fear, misery, illness, and old age. This age of peace and beauty was made especially prosperous thanks the earth's spontaneous and abundant production. A most violent Silver Race succeeded it; created by Olympian gods whom, in its impiety, it failed to honor properly, it was destroyed by Zeus, who replaced it by the belligerent Bronze Race. Born from ash wood, this strong and ugly race disappeared into black and silent Hades. Finally, the short-lived Iron Race knows almost only suffering and worries with neither love nor friendship; offending their parents, its representatives are envious, violent and mischievous, plundering neighboring cities and paying no respect to oaths and justice.

The Graeco-Roman myth of the metallic races has long been recognized to bear close resemblance to the ancient Indian doctrine of the four yugas"ages," "eons," “(cosmic) periods": krtayuga, tretāyuga, dvāparayuga, and, most famous among them, kaliyuga. ${ }^{2}$ In spite of the fact that the metallic symbolism is conspicuously absent in the Indian context (the fouryugas are traditionally reported to borrow their names from the dice game, from the winning throw to the losing throw, see below), the yugas have, from the earliest days of Western indological scholarship as well as among esoteric circles, ${ }^{3}$ been com-

2 By far the best study to date is Luis González-Reimann, The Mahābhārata and the Yugas: India's Greatest Epic Poem and the Hindu System of the World Ages (New York: Peter Lang, 2002). See also Luis González-Reimann, "Cosmic Cycles, Cosmology, and Cosmography," in Brill's Encyclopedia of Hinduism, vol. 1, ed. Knut A. Jacobsen et al. (Leiden: Brill, 2009), 411-28.

3 This was the case, e.g., of William Jones (1746-1794) and Paulinus a Sancto Bartholomaeo (1748-1806; Systema Brahmanicum liturgicum mythologicum civile [Romae: Apud Antonium Fulgonium, 1791]; note, e.g., p. 209—-for you Albert: Adde his, aetates indicas in quatuor dispertiri, et primam quidem krdayugam, vel satyayugam seu veritatis \& iustitiae aetatem usque ad diluvium perdurasse, secundam dvidiayugam dictam, a diluvio seu prima incarnatione Vishnu in piscem incepisse, tertiam tredayugam seu aetatem cupream triginta annis post mortem dei Krshnae, quae ad annum circiter 1000 ante Christum natum reiicienda est, sinivisse, ad circa id tempus kaliyugam seu aetatem ferream incepisse...). Note also René Guénon, La Crise du monde 
pared if not identified with the Hesiodic races/ages. The doctrine finds its first but already mature expression in two closely related second- to third-century CE (parts of) texts, the Manusmrti (Laws of Manu, 1.81-86) and the third book of India's great epic, the Mahäbhärata (e.g., 3.148, 186-189). The four yugas are ascribed descending durations (4,000, 3,000, 2,000, 1,000 years). Each of them being preceded by a period of dawn (400, 300, 200, 100 years) and a period of dusk (same duration), the aggregate period, referred to as a yuga (and later as a caturyuga, "fourfold yuga," or a mahāyuga, "great yuga"), amounts to 12,000 years (a thousand such yugas amount to a Day of Brahmā). The criterion most commonly resorted to in order to estimate this degeneration is the Law (dhar$m a$, behavioral, ritual, social and cosmic order, including, first and foremost, the integrity of the caste-classes and the stages of life), which is said to be diminished by one fourth in each successive yuga. In the same way, "age after age ... virility, wisdom, strength, and influence shrink by one-fourth."4 Cosmological and apocalyptic/millenarian uses of the doctrine can be distinguished according to whether it is intended as a relatively neutral account of the cosmic time structure or, rather, as an ex post facto description (generally in the future tense of prophecy) of the present in terms of the scenario of the End.

If, in spite of ancient India's reluctance for seafaring, the absence of navigation seems not to characterize the krtayuga, the absence of fear and conflicts, the spontaneity of both the Law and nature (with or without sowing and labor) are recurring features of the first age. Other aspects include the absence of gods, diseases, suffering, discontent, pride, envy, and trade. Sacrifice appears in the tretayyuga together with austerities and donations. During the dväparayuga, the Veda becomes fourfold, truthfulness collapses as diseases and disasters increase. Among the countless features of the kaliyuga (or of the yugānta), mention can be made of the fatal deterioration of Law and truthfulness; the end of the Vedic life-rules and rituals; crop failures and drought; social, sexual and dietary disorders; foreign invasions, false policies and plunder; trade, game and taxes, etc. In this dreadful last period, people are short-lived (men turn grey in their sixteenth year), of little vigor and valor; seven or eight-year-old girls become pregnant; women cast off all morals, have intercourse with the mouth

moderne (Paris: Gallimard, 1973 [1946]), 21: "La doctrine hindoue enseigne que la durée d'un cycle humain ... se divise en quatre âges, qui marquent autant de phases d'un obscurcissement graduel de la spiritualité primordiale; ce sont ces mêmes périodes que les traditions de l'antiquité occidentale, de leur côté, désignèrent comme les âges d'or, d'argent, d'airain et de fer." Most sincere thanks are due to Christophe Vielle for his generous help with these and other fascinating materials.

4 Mahābhārata 3.188.13, translation J.A.B. van Buitenen, The Mahābhärata, 2: The Book of the Assembly Hall; 3: The Book of the Forest (Chicago: Univ. of Chicago Press, 1975), 594. 
and, "secretly deceiving their husbands, lasciviously fornicate with slaves and even cattle"5; Vedic students drink liquor and swive their teachers' wives, while the aged behave like children; odors become stench and flavors putrid; the crossroads bristle with jackals, the cows give little milk, and the trees yield few flowers and fruits.

To the best of my knowledge, the two dispositifs have no common IndoEuropean ancestry. ${ }^{6}$ The origins of the four-yuga system remain shrouded in mystery even after Luis González-Reimann's path-breaking study of the ways in which the doctrine made its way into the Mahäbhärata. In spite of various uses of the word yuga as early as the Rgveda (1,500-1,00о BCE; in the sense of a human generation or of an undefined time period) and the mention of longer periods of time (a hundred and ten thousand years) in the Atharvaveda (around 1,00о ВСЕ?), "Vedic literature shows no awareness of large recurring time cycles [and does not] seem interested in the possibility of world destruction" (González-Reimann, "Cosmic Cycles," 412b). Even if Babylonian influences have been postulated concerning the duration of yugas in later, Purānic materials (417b), and if Greek influence on the four descending ages is perhaps not to be entirely ruled out according to González-Reimann (ibid., 416b), hypotheses concerning the origin, the formation and the early history of the doctrine are still very much a desideratum. ${ }^{7}$

To begin with, most scholars seem to take a simultaneous appearance and parallel, organic growth of all four yugas for granted. This scenario looks very unlikely to me. Let me consider first Aśvaghoṣa, a celebrated Buddhist monk, poet and dramatist whose works cannot be later than 100-150 CE, i.e., about one century earlier than the Laws of Manu and the relevant sections of the Mahäbhärata (the latter could be even younger). To begin with, the two intermediate ages, the tretāyuga and the dvāparayuga, are conspicuously absent from Aśvaghoșa's extant writings (the Buddhacarita or Life of the Buddha and the Saundarananda or Handsome Nanda; two fragmentary dramas have come down to us as well). On the contrary, Aśvaghoșa is well acquainted with the krtayuga, to which he alludes several times, e.g., while describing king

5 Mahābhärata 3.186.55; trans. van Buitenen, The Mahäbhärata, 588.

6 Note, however, that Michael Witzel holds the four ages to belong to what he calls "Laurasian mythology." See Michael Witzel, The Origins of the World's Mythologies (Oxford: Oxford Univ. Press, 2012), 86-87.

7 González-Reimann's insightful remarks concerning the Mahäbhärata as a "Kali" poem (conflict, war, bad luck, misfortune) and the felt necessity to "codify" and make time predictable are extremely useful in this connection. See González-Reimann, The Mahäbhärata and the Yugas, 138-163. On Johannes Bronkhorst's views on the passage from conceptions of the (near) end of the (kali)yuga to conceptions of a (long) kaliyuga, which I endorse, and which the present essay makes even more likely in my opinion, see below. 
Suddhodana, the Buddha's father, as "abiding by the law of righteousness of the golden age,"8 or the king's subjects as rejoicing in Kapilavāstu (Śuddhodana's capital city and the Buddha's birth-place, so to say) "as in the golden age of Manu, in happiness, plenty and virtue." ${ }^{9}$ What about the kaliyuga? As far as I can see, the expression does not occur in the Saundarananda and the first part of the Buddhacarita, which has been preserved in its Sanskrit original, but verse 21.64 of the Buddhacarita, which has been preserved in Tibetan, ${ }^{10}$ likely reflects Aśvaghoșa's use of the expression, provided that the Tibetan expression rtsod ldan dus renders the Sanskrit kaliyuga. J.S. Negi's Tibetan-Sanskrit Dictionary (vol. XI [2003], 4756a) records at least one occurrence of Tibetan rtsod ldan dus used to translate kali(yuga), and Tibetan rtsod pa'i dus is well attested as a standard rendering of kaliyuga in other Tibetan-Sanskrit dictionaries. The same stanza (Buddhacarita 21.64) provides us with an additional allusion to the krtayuga (Tibetan rdzogs ldan [gyi] dus) in Aśvaghoșa's writings. As we shall see, the Mahäbhärata and other Brahmanical sources not only describe the kaliyuga, but also the yugānta or "end of a/the yuga," where yuga is likely intended in the sense of the entire four-yuga pattern, or as an unspecified era. ${ }^{11}$ To put it briefly, the yugānta "is a time of great destruction, caused mainly by natural forces: torrential rains, implied by the rolling clouds and the thunder; earthquakes ...; terrible winds ...; and an intense, resplendent Sun; but most of all fire, an all-consuming fire that destroys everything. There are also comets and meteors, as well as negative planetary configurations." ${ }^{12}$ In Buddhacarita 16.30, Aśvaghoșa compares the imperturbable Buddha with Brahmā who "at the end of the great eon ... shines sitting when the conflagration dies down."13 The Tibetan expression E.H. Johnston translates with "(conflagration at) the end of the great eon" is dus mtha'i me, which almost certainly renders the ubiquitous Sanskrit expression yugāntāgni, literally "the fire at the

Saundarananda 2.25c, translation E.H. Johnston, The Saundarananda or Nanda the Fair, Translated from the Original Sanskrit of Aśvaghoșa (London: Humphrey Milford, Oxford Univ. Press, 1932), 10.

9 Saundarananda 3.41cd-42, translation Johnston, The Saundarananda, 19.

10 Derge edition of the Tibetan canon (Bstan' 'gyur) Ge 77b6-7.

11 On the yugānta, see González-Reimann, The Mahäbhärata and the Yugas, 64-73, Johannes Bronkhorst, "The Historiography of Brahmanism," in History and Religion: Narrating a Religious Past, ed. Bernd-Christian Otto et al. (Berlin: De Gruyter, 2015), and below. González-Reimann, The Mahäbhärata and the Yugas, 71.

13 Derge edition of the Tibetan canon (Bstan' gyur) Ge 6oa3, translation E.H. Johnston, Aśvaghoșa's Buddhacarita or Acts of the Buddha (in three parts: Sanskrit Text of Cantos I-XIV with English Translation of Cantos I-XXVIII, Cantos I to XIV translated from the Original Sanskrit supplemented by the Tibetan Version and Cantos XV to XXVIII from the Tibetan and Chinese Versions (Delhi: Motilal Banarsidass, 1984), 17. 
end of a/the yuga." To sum up, Aśvaghoșa is familiar with the krtayuga, the illud tempus of ideal kings and seers (rși), the kaliyuga, and the yugānta, but never refers to the intermediate periods of the tretā- and dvāparayugas.

The Rāmāyaṇa, ancient India's second great epic, reveals roughly similar tendencies. Although the Rāmāyaṇa, like the Mahābhārata, cannot be dated with any degree of certainty (between $500 \mathrm{BCE}$ and $500 \mathrm{CE}$ ?!) and has undergone much reworking, it looks like significant parts of the core narrative (cantos 2-6) were known to Aśvaghoșa in pretty much the same form as the ones we now read, as Gawroński and others have demonstrated. ${ }^{14}$ A quick search into the electronic text of the Rämāyan $a^{15}$ entirely confirms reading notes and impressions: tretāyuga occurs six times in the Rāmāyana, all of them in book 7 (17.31, 65.11-12, 65.17, 67.18, 68.1); dvāparayuga presents the same overall distribution with only four occurrences in book 7 (65.19, 20, 21, 23). Either alone or in compound expressions, kali(yuga) surprisingly only occurs at 7.65.22 (for tisya, a synonym of kali[yuga], see below). Now, the Rämāyana's books 1 and 7 are almost unanimously regarded as later additions. ${ }^{16}$ In other words, the totality of the Rāmāyana's allusions to the tretā-, dvāpara- and kaliyugas (with the possible exception of the tisya occurrence) can safely be considered later additions reflecting conceptions widely attested in the Mahäbhärata and early Purānas. The krtayuga is only slightly better represented with six occurrences in book $7(2.4,17.31,53.3,65.9,70.5,88.8)$, two in book $1(1.73,44.14)$ and two in books 5 (1.108) and 6 (26.13), the only ones justified to claim some antiquity. Rāmāyaña 6.26.13 is certainly the most interesting among them. After revealing that the Blessed One had created two parties, the dharmic gods and the adharmic anti-gods, Mālyavat, a parent of cruel Rāvaṇa, explains that “[when]

14 See Andrzej Gawroński, Studies about the Sanskrit Buddhist Literature, Collected Papers, ed. Marek Mejor (Warsaw: Research Centre of Buddhist Studies, Faculty of Oriental Studies, Univ. Warsaw, 2012 [the article "Studies about the Sanskrit Buddhist Literature" was initially published in 1919]), 102. Gawroński's systematic research was based on book 2. See the digitized Poona critical edition at $<$ http://gretil.sub.uni-goettingen.de/gretil. html\#Ram>, last accessed 26 December 2019.

16 See John Brockington, The Sanskrit Epics (Leiden: Brill, 1998), 379-83 and 391. These two books are regarded as the third stage of growth of the epic, the second stage consisting of various types of inflation (expansion, interpolation) in books 2-6, criteria for which can be either formal/stylistic (ornateness in language and style, long compounds, prosody) or material (Purānic elements, divinity of Rāma, etc.). The addition of stage three is not earlier than the first to second century $\mathrm{CE}$ and may very well be dated to the fourth century $\mathrm{CE}$, if not later. In the Rāmāyaṇa as in the Mahābhārata, this addition "seems ... to be linked with passing from the hands of their traditional reciters ... into those of the brāhmans as the guardians of all traditional learning," and reflects a "process of adaptation to brāhman values" (religious, ethical, cosmological) (Brockington, The Sanskrit Epics, 394). This process also reflects a "shift from oral to written transmission" (p. 395). 
dharma eclipse[d] adharma, then the krtayuga prevailed, [but when] adharma eclipses dharma, then tisya (= kali[yuga]) breaks out." What we actually find in the Rämāyana are comparatively abundant references to the yugānta or "end of a/the yuga," only six of which occur in book 7 (6.55, 7.10, 15.9, 32.38, 61.20, 61.31), and none in books 1-2. Among the twenty-six occurrences of yugānta in books 3-6, twelve refer to the yugāntägni ("the fire at the end of the/a yuga") that we have already encountered in Aśvaghoșa's Buddhacarita, the remaining fourteen referring to other aspects of the final cataclysm (suns, winds, clouds, lightning). The two occurrences of yugakssaye ("at the close/consumption of the/a yuga") in book $6(82.38,88.4)$ point in the same direction. To sum up, the early portions of the Rāmāyana reflect no awareness of the tretāand $d v a \bar{p}$ arayugas. They only rarely allude to the krta- and the kaliyugas (in the form of tisya), operating almost exclusively with the yuganta. The evidence from the Rāmāyana and the works of Aśvaghoṣa suggests that in first-century CE Ayodhyā/Sāketa (the Rāmaite center, of which, according to colophons, Aśvaghoșa was a native), cosmological and eschatological conceptions revolved around the three motifs of an "Edenic" krtayuga (widely used in reference to ideal kingship), a cataclysmic yugānta (most often in the context of similes and metaphors) and a still very discrete kaliyuga/tisya with unspecified mutual connections and no organic pattern of gradual degeneration.

Close attention should be paid in this connection to a curious little text, the so-called Yugapurāna, which, if its tentative dating by its learned editor could be confirmed, would be the earliest extant source concerning the four yugas. ${ }^{17}$ The 115-verse Yugapurāna forms section 41 of the Gärgìajyotișa, a bulky treatise $\left(6,500\right.$ verses) on astral science twice referred to in the Mahäbhärata. ${ }^{18}$ Given that the Mahābhārata explicitly refers to the text's sixty-four divisions, the Gärgìajyotișa likely was known to its redactors "in a form at least very similar to its present form" (Mitchiner, The Yuga Purāna, 10). From the fact that the Gärgìajyotișa and the Yugapurạna refer to the Indo-Greeks (yavana) and the Indo-Scythians (śaka) but not to later groups of foreign invaders such as the

17 See González-Reimann, "Cosmic Cycles," 415a, and John E. Mitchiner, The Yuga Purāṇa, Critically Edited, with an English Translation and a Detailed Introduction (Calcutta: Asiatic Society, 1986), vii. The overall interpretation of the Yugapurāna is my main, and basically unique, point of disagreement with González-Reimann, who, while apparently assenting to Mitchiner's chronology, regards the text as a forerunner and possible source for the Mahābhārata's (and, for this reason, the Vāyuproktam purānam, "the purāna revealed by [the god] Vāyu") attempt to locate the epic events in the yuga scheme (see below). See González-Reimann, The Mahäbhärata and the Yugas, 98-99 and 142.

For a summary of the Gārgīyajyotișa, see David Pingree, Jyotihśāastra, Astral and Mathematical Literature (A History of Indian Literature VI, 4) (Wiesbaden: Otto Harrassowitz, 1981), 69-72. 
Pahlavas, the Kuṣannas, the Tuṣāras and the Hūṇas, J. Mitchiner deems it "reasonable to suggest at this stage a date of the composition of the Gärgìajyotișa as a whole during the period of Indo-Greek rule and presence in India, and before the Indo-Parthian and Kuṣanana invasions: namely some time prior to c. AD 25" (p. 11). Mitchiner's final estimate is $25 \mathrm{BCE}$, about one century before Aśvaghoșa. Mitchiner (pp. 14-16) sees no reason to doubt the authenticity of the Yugapurāna as an integral and original part of the Gärgìyajyotișa: this section conforms in language, form and style to the rest of the treatise; the name purāna is given to other sections of the work as well; all extant complete manuscripts of the Gärgìyajyotișa contain the Yugapurāna chapter; no independent manuscript of the Yugapurāna or any other part of the work has come to light. As for the unity of composition of the chapter, it has received only little attention from the editor: judged on metrical criteria, "the text of the Yugapurāna is on the whole reasonably unitary" (p. 14).

The text presents itself as a cosmological-historical exposition delivered by Śankara/Śiva in answer to a set of questions posed by Skanda: "What was the nature of the Time which has gone by in the past, and what is to be the nature [of Time in the future]? What [will be] the length of life and what the bodily form of living beings: and what also will be the strength of tapas (ascetic practices) at the end of the Yuga? What [will be] the degree of authority at the start of the Yuga, and the dharma (forms of righteous conduct) in each Yuga: and at the end of the Yuga, [what] will be the state of affairs at that time, O Lord of Creatures?"19 Śiva's answer consists in an account of the four yugas (vv. 6-37): krtayuga (vv. 6-14), tretāyuga (vv. 15-22), dvāparayuga (vv. 23-36), and kaliyu$g a$ (vv. 37-113). During the krtayuga of supreme virtue, fear, death, thieves, greed, anger, passions, deceit, depravity and sexual union were unknown; trees bore fruit at will and the earth was full of corn; gods and other supernatural beings were born, and the humans' life-span amounted to 100,000 years.

The krtayuga ended with a big battle at the end of which Brahmā created the aristocratic and military caste (kșatra, i.e., kșatriyas). Women, the four caste-classes, sacrifices, treatises and mantras appeared during the tretāyuga; humans were upright and not deceitful, dedicated to dharma and their own socio-religious duty; their life-span decreased to 10,00o years as anger and greed descended upon the surface of the earth. Rāma (Paraśurāma or Jāmadagnya, not the hero of the Rāmāyaṇa) caused the disappearance of the entire caste of the warriors (likely to avenge the death of his father at their hands). In spite of the fact that truth, righteousness and sacrifices remained, and one quarter of the dharma was left, the dvāparayuga proved "terrible" (ghora), with

19 Yugapurāṇa 1cd-3, translation Mitchiner, The Yuga Purāṇa, 87. 
a decrease of the life-span to 1,00o years and an apocalyptic war causing the destruction of the earth, men, and kings. ${ }^{20}$ This war is none other than the one narrated in the Mahābhärata, the most important characters of which are mentioned by name, including Keśava (= Viṣnu) in the form of Vāsudeva (= Kṛṣna). The description of the kalìuga, starting with king Pārīkșit (vv. 38-39), occupies the rest of the chapter, where general descriptions of the gloomy last age (vv. 50-55, 82-86, 90-94) alternate with seemingly historical characters and narratives. ${ }^{21}$ The Yugapurāna's description of the kaliyuga ends with an optimistic note. Calm, patience and self-restraint, as well as the firm upholders of Brahmanical values, will remain at the consumption of the yuga as twelve regions (mandala) are created with a view to the welfare of surviving living beings (vv. 95-113) in a climate that is evocative of the dawn of a new krtayuga (the expression does not occur in this context).

The Yugapuranna's account of the kaliyuga seems odd. The expression kaliyuga appears three times at the very outset of the account (vv. 37, 38, 40) and then entirely disappears. ${ }^{22}$ What one finds instead are repeated allusions to the end of the yuga, most of which occur in refrain-like manner at the end of (half-)verses in the form yugakșaye, "at the consumption/close of the yuga." This pattern is reflected in no less than eleven verses $\left(5^{\circ-51}, 95^{-97}, 99,102-\right.$ $104,110,113)$, an additional one consisting in the equally formulaic yugānte samupasthite, "when the end of the yuga is at hand" (v. 53). This, together with the "yuga's end" of v. 91, suggests that the major part of vv. 37-113 was intended as a description, not of the kaliyuga, but of the yugānta. ${ }^{23}$ The pattern is clearly reminiscent of at least two passages in the Mārkandeya section of the Mahäbhärata (3.186-189). In 3.186, the relevant segment (vv. 24-55) occurs immediately after a general outline of the four-yuga system (vv. 17 cd-23) that reflects the same doctrine as the Laws of Manu (1.81-86). Eight references to the

20 The use of the future tense starts with the description of the end of the dvaparayuga, suggesting that Śiva's exposition takes place before the Mahābhārata battle. The Yugapurāna is thus as much a narration of the past as a prophecy.

21 Foundation of Pātaliputra by Udāyin together with subsequent events connected to kings Śāisśūka, Sādhuketa and Vijaya (vv. 40-46), disorders caused by the invasion of the IndoGreeks (vv. 47-48 and 56-57), the desolation caused by the seven mighty kings of Sāketa and the Agniveśyas (vv. 58-61), appearance of the king of the Śakas (vv. 62-65), events connected with kings Āmrāța/Lohitākṣa, Gopāla, Puṣpaka, Anaraṇya, Vikuyaśas, Agnimitra (vv. 66-78), Agniveśya and his struggle against the Śabaras (vv. 79-81), king Śatuvara and the massacres caused by the Śakas (vv. 87-89).

22 I am not inclined to interpret kalipriyam in v. 96 as a reference to the kaliyuga.

23 An additional feature of the passage is the repeated, here again refrain-like occurrence of na (atra) samśayah, generally at the end of the verse. The pattern is reflected in vv. 38,42 , $48,5^{\circ}-52,54,57,64,78,85,92$. 
yugānta can be numbered (against one for the kaliyuga, v. 27), three of which consist of end-of-verse yugakșaye, "at the consumption/close of the yuga" (vv. $35,42,48)$. Most striking is, however, 3.188. The passage presents itself as Mārkandeya's answer to Yudhișțira's question about the kaliyuga, which he makes every impression of deliberately equating with the end of the yuga (see vv. 4-7). Here again, the passage opens with a short outline of the four yugas (vv. 9-12). This short introduction, in which the kaliyuga is not explicitly mentioned, reflects the "orthodox" doctrine of the descending four quarters of the dharma. The seventy-one verses that follow (vv. 13-84) contain no less than thirty-eight explicit references to the end of the $y u g a,{ }^{24}$ all of them in the locative, and more or less with the same meaning ("at the end of the yuga"):yugānte paryupasthite (vv. 19, 35-37, 39, 43-44, 47, 54, 76, 81, 83), yugakșaye (vv. 20-23, 25, 32-33, 41, 50-51, 78, 85), yugānte (vv. 49, 53, 66, 73, 79), yugasañkșaye (vv. 55, 62, 64), gate yuge (v. 69), yuge kșine (v. 66), and tadā sañkșepsyate yugam ("then the yuga will end," vv. 59, 67-68). There is little doubt in my opinion that the original intent of this passage was the yugānta, not the kaliyuga. Yugapurāna 37-113, Mahäbhärata 3.186 and 3.188 thus seem to exhibit a very similar structure in which a lengthy development dedicated to the yuganta is introduced, and sometime concluded, by a generally much shorter and ideologically standardized outline of the four (or only three) yugas. In all cases, this reorganization results in the yugānta becoming the end, not of an unspecified era, as it originally was in my opinion, but of the kaliyuga, hence of a four-yuga period. I cannot resist the impression that, in those three passages, original apocalyptic/prophetic accounts of the yuganta were provided with a new meaning by incorporating them into the alien and most probably more recent framework of the four yugas.

These three passages have another feature in common. As we have seen, the Yugapurāna lays strong emphasis on the political events to take place at the end of the yuga. Some at least among these events pertain to intruding barbarian $(m$ lecch $a)$ kings or groups such as the Indo-Greeks, the Indo-Scythians, and king Āmrāța/Lohitākșa. The Indo-Greeks, "infatuated by war," (v. 56), are made responsible for the ruin of Pātaliputra (modern Patna), various disorders, and a great war. The mighty king of the Śakas is "greedy for wealth," "vicious," "evil" and "goes while plundering," and "when the Śaka realm has been destroyed, the earth will be desolate." 25 "Then the terrible Śaka will cause the peoples, acting for their own destruction..., to be also scattered.... He will destroy a quarter of living beings by arms; [while] the Śakas will take a quarter of the

24 Including paścime kāle, "in the final period/time" (v. 52).

25 Yugapurāṇa vv. 62-64, translation Mitchiner, The Yuga Purāna, 93. 
wealth to their own city."26 As for Āmrāța the Mleccha, "red-eyed and wearing red garments, having robbed the helpless people, [he] will then cause them to be destroyed. Then that king will destroy the four varnas [caste-classes, VE]."27 To be sure, the barbarian kings have no monopoly over political and social violence in the Yugapurāna, but they are indiscriminately regarded as evil. Consider now Mahābhārata 3.186.29-31: "Many barbarian kings, O overlord of men, will rule the earth with false policies, being given to evil and lies. Āndhras will be kings then, Scythians, Pulindas, Greeks, Kambojas, Aurnikas, serfs, and Ābhīras. Not a brahmin then lives by his own Law, and likewise the barons and commoners work at the wrong tasks, O king." ${ }^{28}$ As for Mahäbhärata 3.188, it exhibits a refrain-like statement to the effect that at the end of the yuga "the entire world is/will be barbarized" (mlecchabhūtam jagat sarvam, vv. 29, 37, 45). Other references to barbarians in 3.188 include vv. $5^{2}$ ("all men will be omnivorous barbarians, cruel in all their deeds") and 70: "The earth will soon be overrun by barbarians, while the brahmins, out of fear of the tax burden, flee in all the directions." ${ }^{29}$ The Yugapurāna is certainly unique in its insistence on the political factors at play at the end of the yuga, but all three texts refer, sometime in a fairly insisting manner, to barbarian rule and habits as sure signs and decisive causes of the End. ${ }^{30}$

As suggested above, Mahābhārata 3.186 and 188 seem to betray a recontextualization of passages originally dedicated to the yugānta. Now, can the kaliyuga/yugānta part of the Yugapurāna (vv. 37-113) be shown to have undergone a similar process of "adaptive re-use"? In other words, can the initial outline of the first three yugas and the beginning of the "kaliyuga" section be shown to be anachronistic? Towards the end of the tretāyuga section, the Yugapurāna mentions (Paraśu)rāma (v. 22); a few verses below, at the end of the dvāparayuga section (v. 30), it refers to Vāsudeva ( $\approx$ Kṛ̣ṇa). At least as far as Vāsudeva is concerned, these allusions have nothing anachronistic in themselves: by the putative date of the text (25 BCE), Vāsudeva was a well-known figure referred to not only by the grammarian Pāninini (fourth century вСЕ; Aștāadhyāȳ̄ 4.3.98), but also by several second- to first-century вСЕ epigraphs such as, e.g., Heliodoros's (a Greek ambassador in Taxila) famous Garuḍa pillar inscription at

\footnotetext{
26 Yugapurāṇa vv. 88-89, translation Mitchiner, The Yuga Purāṇa, 95.

27 Yugapurāna vv. 68-69, translation Mitchiner, The Yuga Purāna, 93.

28 Translation van Buitenen, The Mahäbhārata, 586-87.

29 Translation van Buitenen, The Mahābhärata, 595-96.

30 See Vincent Eltschinger, Buddhist Epistemology as Apologetics (Vienna: Austrian Academy of Sciences Press, 2014), 34-72, Bronkhorst, "Historiography," 29-32, González-Reimann, The Mahäbhārata and the Yugas, 97 .
} 
Besnagar. ${ }^{31}$ In addition, Vāsudeva-Kṛ̣na is represented with four arms, a conch, a disk, and a mace (the attributes of the "future" Hindu god Viṣnu) from the end of the first century вСE (Malhār/Bilaspur in Central India; see Schmid, Don de voir, 112-118), so that at least part of what follows need not surprise us (Yugapurāna vv. 29-30): "Keśava will arise at the end of the Dvāpara, in order to destroy horses and elephants, princes and men; [he will be] four-armed, of great valour, bearing the conch, disk and mace: [and he will be] called Vāsudeva, the strong one, dressed in yellow clothes." ${ }^{32}$ What is striking about this passage is that it opens the Yugapurāna's detailed account of the Mahäbhärata's plot and personnel (vv. $3^{1-36}$ ), which the text thus locates at the close of the dvāparayuga (this has been the most current view about them from Purānic Hinduism onward):

Then, resembling Kailāsa, wearing a garland of flowers [and] bearing the plough as weapon, there will arise Yudhișthira - the excellent king of the Pândavas - for the purpose of slaughter at the end of the Dvāpara, together with [his] four brothers: [namely] both Bhimasena the son of Vāyu, and Phālguna of severe tapas [austerity, VE], and the two brothers Nakula and Sahadeva, born of the Aśvins. Also Bhīṣma, Droṇa and others, and the prince Dhṛstadyumna: and Karna, the king of Anga, together with Aśvatthāman the invincible; Devala and Śatadhanvan, and Dāruka the illustrious - they will arise at the end of the Yuga, in order to protect the world of men. So too Śakuni and Dantavaktra, and Śiśupāla the haughty: together with Śalya, Rukmi, Jarāsandha, Kṛtavarman [and] Jayadratha. The cause [of strife] of these mighty kings will be Kṛnnā, the daughter of Drupada: [and] the earth will go to [her] destruction. ${ }^{33}$

As demonstrated by González-Reimann, ${ }^{34}$ however, the Mahābhārata's own statements to the effect that its plot would belong to the end of the dvāparayuga (and that Kṛnna's death would open the kaliyuga) are extremely scarce, isolated, and demonstrably late — as is, of course, the Mahābhārata's own summary of contents at 1.2 (Brockington, The Sanskrit Epics, 135), where such claims find their first expression in the great Epic (Mahäbhärata 1.2.9: "And once the junc-

$31 \quad$ On the early history of Vāsudeva-Kṛṣna, see Charlotte Schmid, Le Don de voir: Premières représentations krishnaïtes de la région de Mathurā (Paris: École française d'ExtrêmeOrient, 2010). See also Gérard Colas, "Bhāgavatas," in Brill's Encyclopedia of Hinduism, vol. 3, ed. Jacobsen et al. (Leiden: Brill, 2011), 295b.

32 Translation Mitchiner, The Yuga Purāna, go.

33 Ibid.

34 See González-Reimann, The Mahābhärata and the Yugas, 86-107. 
ture of the kali and the dväpara was reached, there was a war between the armies of the Kauravas and the Pānd davas in Samantapañcaka"). In other words, if Mitchiner's early chronology were to be accepted, the author(s) of the Yugapurāna would be the first witness(es), and likely inventor(s), of a central theological-mythological complex that only appears about three centuries later in the Mahābhārata itself. Considered in this light, the verses on Keśava appearing as Vāsudeva (vv. 29-30) are perhaps liable to a different interpretation. The text's reference to the four arms, the conch, the disk, and the mace could very well refer to Viṣnu himself, in which case Vāsudeva(-Kṛṣna) could be understood as a manifestation of the latter (Keśava appears with the name Vāsudeva), even if the vocabulary of traditional Vaișnava theology (avatāra, prādurbhāva, vyūha, etc., all meaning something like "manifestation" or "embodiment") is not represented in our text. Now, this would be incompatible with a late first-century BCE date given that even the Bhagavadgit $\bar{a}$ (first to second century CE) does not consider Kṛ̣na, its main protagonist, to be a manifestation of Viṣnu.$^{35}$ Clear allusions to Vāsudeva-Kṛṣna being a manifestation of Viṣnu seem not to be attested before late strata of the Mahäbhärata such as the first (1.61.9o, amśáavatarana, "partial embodiment") and especially the twelfth books (12.326.61, etc., prādurbhāva, "appearance"). According to A. Malinar, "[a]lthough there are some epic passages in which Kṛ̣na is considered to be identical with the god Viṣnu or is addressed as Viṣnu, this identification, making Kṛṣna an embodiment (avatāra) of Viṣnu, seems to have been a later development. The earliest sources, in which Kṛṣna becomes part of a Vaiṣnava genealogy and which turn him into one of the various embodiments of Viṣnu, are the Harivamśa (second to third cents. CE) and the Vișnupurāṇa (third to fourth cents. CE)." ${ }^{36}$ As we have seen, moreover, the Yugapurāna describes Vāsudeva as "dressed in yellow clothes." The motif may presuppose passages such as Mahābhärata 3.148, which associate different colors (and names) with Viṣnu in each yuga: Nārāyaṇa is white in the krtayuga; Acyuta is red in the tretāyuga; Viṣnu is yellow in the dvāparayuga; and Keśava is black (krṣna!) in the kaliyuga. As for the Yugapurāna's allusion to Rāma (v. 22-23a), "at the end

35 The Bhagavadgitta (vv. 4.6-7), however, is often regarded as providing a first general concept of the motif: "Although I am unborn and imperishable and the lord of the creatures indeed, I transform nature (prakrti) that is mine and take birth through an appearance of myself (ātmamāyā). For whenever the Law (dharma) languishes, Bhārata, and lawlessness (adharma) flourishes, I create myself. I take on existence from eon (yuga) to eon, for the rescue of the good and the destruction of the evil, in order to reestablish the Law." Translation as in André Couture, "Avatāra," in Brill's Encyclopedia of Hinduism, vol. 2, ed. Jacobsen et al. (Leiden: Brill, 2010), 702a.

36 Angelika Malinar, "Kṛșna," in Brill's Encyclopedia of Hinduism, 1: 6ogb. 
of the Tretā Yuga ... the earth was made devoid of kṣatriyas thrice-seven times by Rāma. Then, when the Kșatra had been destroyed...,"37 it is likely to presuppose passages such as Mahābhārata 3.117.9: "Twenty-one times the lord emptied the earth of barons [kșatriyas, ve]." As far as I can see, however, this passage of the Mahābhärata does not associate the famous episode of Rāma's revenge with the tretāyuga. Such an association seems only to appear, again, in the Epic's summary of contents at Mahäbhärata's 1.2.3: "At the juncture of the tretā and the dvāpara [yugas], Rāma the best among warriors several times destroyed all the terrestrial kșatriyas (pärthivam kșatram)." The parallelism cannot be clearer: in addition to the episode itself, both passages refer to the earth (mahi, pärthiva) and to the kșatra (military order/power; the kșatriyas as a whole). In both Mahäbhärata 1.2 and the Yugapurāna, the only two stories narrated in this particular context are those of Rāma and Vāsudeva.

To sum up, close consideration of the tretā-and dvāparayuga sections of the Yugapurāna suggests their author's likely indebtedness to late (second to fourth century CE?) strata of the Mahäbhärata and perhaps other texts such as the Harivamiśa and early Purānas. Alternatively, if the Yugapurāna is to be regarded as the source of the epic and early Purānic accounts, as Luis GonzálezReimann is inclined to believe, its elaboration on the four yugas - say, perhaps vv. 1-46-must postdate $25 \mathrm{BCE}$, unless one has to credit this short and rather isolated text with several major innovations in Indian religious history, such as Vāsudeva(-Kṛṇna) as a manifestation of Keśava(-Vișnu) and the assignment of Rāma to the juncture of the tretā- and dvāparayugas and of Vàsudeva and the Mahäbhärata to the juncture of the dvāpara- and kaliyugas. In addition, the Yugapurāna would have to be the model for these two stories' being the only ones narrated at the outset of Mahäbhärata 1.2; for the episode of Rāma Jāmadagnya emptying the earth of all kșatriyas; for other aspects such as the role played by Time ( $k \bar{a} l a$ ) in the two accounts (compare v. 28 with Mahäbhārata 1.2.25); and for numerous aspects of the legends of kings Janamejaya Pārìkṣit, Udāyin, and Saaliśūka that seem only to be attested in Purāṇic literature (Mitchiner, The Yuga Purāna, 51-55). In short, the presence of all these motifs in a text from the first century вСЕ looks very implausible to me. To be sure, the Mahäbhärata twice refers to the Gärgìajyotișa, but this does not mean that the author(s)/compiler(s) of the relevant sections of the Epic were acquainted with the Yugapurāna, at least in its present form. There are in my opinion some reasons to believe that the four-yuga framework of the Yugapurāna is a late addition intended to recontextualize an older, possibly end-of-the-first-century вСЕ account, not of the fouryugas, but of the yugānta, "the end of the yuga." 
The formal, compositional and doctrinal features of the Yugapurāna, Mahābhārata 3.186 and 3.188 seem to point to two distinct layers: older apocalyptic accounts of the yugānta (first century BCE to second century CE?), ${ }^{38}$ and a later reframing of these prophecies made in order to align them with the new Brahmanical, essentially Vaiṣnava ideas concerning cosmology and, in one case at least, the historical manifestations of Viṣnu (second to fourth century $\mathrm{CE}$ ?). ${ }^{39}$ In my opinion, this is likely to give even more weight to J. Bronkhorst's hypothesis that the (late Epic/early Purānic) conception of a long kaliyuga with a distant end imposed itself when apocalyptic expectations relating to the near end of the (kali)yuga proved wrong.

I am inclined to believe that the doctrine of the four yugas was still unknown to the authors/redactors of the Rāmāyaṇa (books 2-6) and Aśvaghoșa in first-century CE Sāketa/Ayodhyā and surroundings, even if, strictly speaking, their silence does not make such a conclusion necessary. Their eschatological conceptions revolved around fairly widespread ideas concerning a cataclysmic yugānta; both texts testify to a belief in a "Golden Age" of celebrated kings and rșis increasingly referred to as the krta(yuga) and, albeit sparsely, to some acquaintance with a degenerate time period named the kali(yuga), which could correspond in time with the Mahäbhärata's ubiquitous allusions to its own events as being kali, i.e., entailing conflict, war, bad luck, and misfortune. In addition, the chronology of the Yugapurāna (or at least parts of it, $25 \mathrm{BCE}$ ), a text that has often been regarded as the earliest extant witness to the four-yuga system, is far from warranted. I would thus hypothesize that the doctrine of the four yugas developed some time between the late first century and the late second century CE, likely on the basis of an analogy with the dice game. Once $k r t a$ and kali were, so to speak, posited, those who created the new cosmology could easily resort to the terminology of the dice throws in order to fill in the new structure and give it a more distinctly degenerative physionomy. ${ }^{40}$ As shown by González-Reimann, the Laws of Manu testify to a similar attempt while reinterpreting two verses from the Aitareyabrāhmana (6оо вСЕ?) in which this terminology was used in order to indicate good and bad fortune. In

38 For a partial anticipation of this hypothesis, see González-Reimann, The Mahābhärata and the Yugas, 72 .

39 On the "Vaisnava appropriation" of the Epic by means of the doctrines of the avatäras and the yugas, see González-Reimann, The Mahābhārata and the Yugas, 103 and 151.

40 Think of the four Dalton brothers in the French comic book Lucky Luke by Morris and René Goscinny: only the smallest (Joe, the most stubborn and cruel of the four) and the tallest one (Averell, the most stupid and tender of the four) matter. The two intermediate brothers Jack and William play no other role in the narrative than suggesting a gradation in stupidity and cruelty. 
the Brāhmana, these verses are as follows: "The fortune of one who is sitting down, sits down; that of one who is standing, stands up. That of one who is lying down, lies down; the fortune of one who keeps moving, moves. Lying down one becomes Kali; getting up, Dvāpara. Standing, one becomes Tretā; by moving, one becomes Krrta." ${ }^{11}$ While reinterpreting these stanzas in the framework of political theory, the Laws of Manu (9.301-302) turn the metaphor of the dice throws into a yuga metaphor ${ }^{42}$ : "The sum of the king's actions determines the Kṛta, the Tretā Yuga, the Dvāpara and the Kali, for the king is said to be the yuga. Asleep, he becomes the Kali; awake, the Dvāpara Yuga; ready to act, the Tretā; and when acting, the Krrta Yuga." ${ }^{33}$ As we have seen, the Laws of Manu are generally regarded, together with the Mahäbhärata, as the earliest extant witness to the conception of the four yugas. This is not to say that the author(s) of the Laws of Manu, or of the relevant sections of the third book of the Mahābhārata, were the creators of the motif (Mārkanḍeya claims his revelation at Mahäbhärata 3.186-189 to be based on the Vāyuproktam purānam, "the purāna revealed by Vāyu," Mahābhārata 3.189.14), but it seems very likely to me that they belonged to the same milieu, and lived very close in time to its invention.

Whatever the relevance of the chronology suggested above, it seems likely that the four yugas did not originate as an organic system, but as a result of gradual accretion and ideologically motivated decisions made in order to update older cosmological and eschatological conceptions. Such a scenario is very unlikely to have led to the formation of the Hesiodic myth of the metallic races/ages, whatever the merits of Jean-Pierre Vernant's hypothesis. ${ }^{44}$ The Greaco-Roman myth of the four/five ages and the Indian system of the four yugas present a clear case of superficially comparable structures, close historical analysis of which betrays logics and ideologies divergent enough to ruin every attempt at a heuristically fruitful comparison.

$41 \quad$ Aitareyabrāhmaṇa 7.15 (33.3.3-4), translation González-Reimann, The Mahābhārata and the Yugas, 122.

42 Adapted from González-Reimann, The Mahābhārata and the Yugas, 123.

43 Translation, ibid.

44 Jean-Pierre Vernant, "Le mythe hésiodique des races. Essai d'analyse structurale" (1958), in Vernant, Oeuvres, Religions, Rationalités, Politique (Paris: Seuil, 2007), 1: 255-80. 